determine the erythrocyte transketolase (ETK) activity or thiamine pyrophosphate (TPP) effect on admission, or thiamine excretion. Tanphaichitr et $a^{3}$ state that thiamine excretion alone is not a good index of the state of thiamine nutrition in an individual subject. The absence of cardiac and central nervous system manifestations may be explained partially by the fact that the patient restricted drinking and did not increase the amount of physical exercise that she took.

The potential threat of dry and wet beriberi should be kept in mind if a patient begins a strict slimming diet. Multivitamin preparations are indicated in treating the condition, but a reasonably composed diet is of primary importance.

We thank Professor Eero Hokkanen for his help in writing this report and Associate Professor Timo Kosunen for the serum B vitamin measurements.

${ }^{1}$ Riding, J, British Medical fournal, 1975, 3, 79.

2 Vinken, P J, and Bruyn, G W (ed), Handbook of Clinical Neurology, vol 28, p 1-41, 49-57. Amsterdam, Elsevier-North-Holland, 1976.

3 Tanphaichitr, V, et al, American fournal of Clinical Nutrition, 1970, 23, 1017.

(Accepted 2 August 1977)

University of Oulu, Oulu, Finland

$\mathrm{K}$ A SOTANIEMI, MD, resident neurologist

$\mathrm{K}$ KAARELA, MD, internist, department of internal medicine

\section{Acute poisoning with Potter's Asthma Remedy}

There has been recent concern in the press ${ }^{1}$ about the increasing abuse of the popular nostrum Potter's Asthma Remedy (Potter and Clarke, Warlingham, Surrey). The active constituent of this mixture is stramonium, derived from the vegetable alkaloid contained in thornapple leaves (Datura stramonium), equivalent to $0.12 \% \mathrm{w} / \mathrm{w}$ of alkaloids calculated as hyoscyamine. It is sold as a brown powder, in a $90-\mathrm{g}$ tin, the burning and inhalation of which is reputed to have beneficial effects on asthma. We report four cases of deliberate ingestion of this preparation because of its hallucinogenic effects.

\section{Case reports}

Case 1-A 16-year-old unemployed youth was admitted to hospital after an emergency call. He was hallucinating, with slurred speech, and was semiconscious, flushed, feverish, and responded to pain, but not to commands. Respiratory excursions were increased with a respiratory rate of $40 / \mathrm{min}$. The pulse rate was $130 / \mathrm{min}$ with frequent atrial extrasystoles. His pupils were widely dilated and responded sluggishly to light; his limbs were flaccid with brisk tendon reflexes and extensor plantar responses. There was no neck stiffness. Urgent inquiries among his friends elicited the information that he had drunk half a tin of Potter's Asthma Remedy, mixed with tea, two hours before. As a result of the inquiries cases 2,3 , and 4 also presented.

Cases 2, 3, and 4-These were friends of the first patient. They admitted to having consumed smaller amounts of the offending substance, and they showed the autonomic side effects of alkaloid ingestion without central manifestations. They had the typical features of atropine-like toxicitymydriasis, blurred vision, dry mouth, and tachycardia. They were observed overnight without specific treatment, and discharged the next day.

The first patient underwent gastric aspiration and lavage and was given physostigmine salicylate $2 \mathrm{mg}$ intramuscularly two-hourly to a total of six doses. He did not require endotracheal intubation or assisted ventilation. Cardiac monitoring was carried out, and a sinus tachycardia, but no further ectopic beats, was recorded. He gradually regained consciousness, and could obey commands after six hours. He was fully recovered 18 hours after admission, and was discharged two days later.

\section{Comment}

Signs of alkaloid overdosage were dramatically described in 1939 as "hot as a hare, blind as a bat, dry as a bone, red as a beet, and mad as a hen.". Our first patient had blurred vision, rapid respiration, tachycardia, confusion, excitement, and coma. The suggested treatment is gastric lavage, sedation with a short-acting barbiturate if necessary, and physostigmine salicylate 1-2 mg intramuscularly or intravenously every 1-2 hours. Oxygen and assisted respiration may be necessary. Neostigmine is of doubtful value, as it does not gain entry to the central nervous system.

Some 10 years ago there were reports from North America on misuse of substances containing stramonium, ${ }^{3}$ and recently two reports on the ingestion of asthma cigarettes in Edinburgh and King's Lynn. ${ }^{4}$ Apparently the misuse of this proprietary preparation is now sufficiently widespread in Britain for the substance to be named "goon dust" in certain circles. A disturbing feature is that one of our patients stated that a front-page article in the press had given them the idea of experimenting with the compound. ${ }^{1}$ Review of our hospital records showed that four other cases of ingestion of "Potter's Asthma Remedy" had been admitted in the past four months. These were teenagers taking the drug for "kicks."

As there is concern about possible exploitation of this substance through "underground" channels ${ }^{1}$ and its continuing availability, we felt that these case reports and records of treatment might be of value.

1 Sunday People, 26 June 1977.

2 Morton, H G, et al, Fournal of Pediatrics, 1939, 14, 755.

${ }^{3}$ Wilcox, W P, New England fournal of Medicine, 1967, 277, 1209.

${ }^{4}$ Harrison, E A, et al, British Medical fournal, 1976, 2, 1195.

${ }^{5}$ Ballantyne, A, et al, British Medical fournal, 1976, 2, 1539.

(Accepted 24 August 1977)

Walsgrave Hospital, Coventry CV2 2DX

A H BARNETT, BSC, $\mathrm{MB}$, senior house officer in medicine

$F$ W JONES, BSC, $M B$, house officer in medicine

E R WILLIAMS, MD, MRCP, consultant physician

\section{Heart disease in life-long cyclists}

The place of exercise in preventing heart disease remains uncertain. ${ }^{12}$ I thought that a survey of one of the cycling organisations catering for older cyclists would be of interest. Cycling tourists are a unique group as they tend to start young and many can and do continue into old age.

\section{Subjects, methods, and results}

The subjects were members of the Fellowship of Cycling Old Timers (FCOT), which was chosen arbitrarily, and the study was by questionnaire. The club was formed in 1965 for cyclists aged over 50 years. There was an $89.5 \%$ response to the 329 forms sent to live members, all but one in the British Isles, and most in England. Details of the cause of death of dead members (23) were obtained from death certificates. Women (12) were excluded from the study. No members had resigned at the time of the study (1973).

The pattern of activity that emerged was 5000-10 000 cycling miles a year in the early years, which fell to 2000 miles in later years. Seventy five per cent of members were still cycling regularly throughout the year, and 54 of the over-70s were cycling once a week or more throughout the year. A positive family history of heart disease was found in 45 cases. Only 23 members

Incidence and episodes of ischaemic heart disease and myocardial infarction in cyclists compared with equivalent age groups in National Morbidity Study (1971). (NMS figures in parentheses)

\begin{tabular}{|c|c|c|c|}
\hline & $45-64$ & $65-74$ & $\geqslant 75$ \\
\hline $\begin{array}{l}\text { No of cyclists } \\
\text { No of years at risk } \\
\text { Episodes of myocardial } \\
\text { infarction } \\
\text { Episodes of ischaemic heart } \\
\text { disease: } \\
\text { Type } 1^{*} \\
\text { Type II } \\
\text { Incidence of myocardial } \\
\text { infarction: } \\
\text { Per } 1000 \text { cyclist } / \text { year } \\
\text { Per } 1000 \text { patient year } \\
\text { Incidence of all ischaemic } \\
\text { heart disease }\end{array}$ & $\begin{array}{c}1(586) \\
1(544) \\
\\
3.9 \\
11.5 \\
3.9(16.3)\end{array}$ & $\begin{array}{c}3(294) \\
8(340) \\
\\
11 \cdot 7 \\
19 \cdot 2 \\
18 \cdot 7(36 \cdot 4)\end{array}$ & $\begin{aligned} 56 & (4388) \\
253 & (4388) \\
1 & (80)\end{aligned}$ \\
\hline
\end{tabular}
*Episode occurring before study, as defined in NMS.
+Episode occurring during study, as defined in NMS 